\title{
Profil Protein Darah Sapi Perah Masa Transisi dengan Indigofera zollingeriana Sebagai Pengganti Konsentrat Serta Penambahan Mineral dalam Pakan
}

\author{
A. H. Permana ${ }^{1}$, I. Hernaman ${ }^{2 *}$, N. Mayasari ${ }^{2}$ \\ ${ }^{\text {I} P r o g r a m ~ M a g i s t e r ~ I l m u ~ P e t e r n a k a n, ~ F a k u l t a s ~ P e t e r n a k a n, ~ U n i v e r s i t a s ~ P a d j a d j a r a n, ~ S u m e d a n g, ~ I n d o n e s i a ~}$ \\ 45363 \\ ${ }^{2}$ Staf Pengajar Departemen Nutrisi Ternak dan Teknologi Pakan, Fakultas Peternakan, Universitas \\ Padjadjaran, Sumedang, Indonesia 45363
}

\begin{abstract}
ABSTRAK
Penelitian ini bertujuan untuk mengetahui dinamika profil protein (total protein, albumin dan globulin) plasma darah sapi perah pada masa transisi dengan Indigofera zollingeriana sebagai pengganti sebagian konsentrat serta penambahan mineral dalam pakan. Penelitian ini menggunakan metode eksperimental dengan Rancangan Acak Lengkap (RAL). Dua puluh sapi perah Friesian Holstein $(F H)$ dengan usia kebuntingan 7-8 bulan dibagi ke dalam empat perlakuan yaitu IZ0=45\% Rumput Gajah $+55 \%$ Konsentrat, IZ15 $=45 \%$ Rumput Gajah $+40 \%$ Konsentrat $+15 \%$ Indigofera zollingeriana, IZ0M $=45 \%$ Rumput Gajah $+55 \%$ Konsentrat $+0,3 \mathrm{mg} / \mathrm{Kg}$ BK Se $+40 \mathrm{mg} / \mathrm{kg} \mathrm{BK} \mathrm{Zn,} \mathrm{IZ15M}=45 \%$ Rumput Gajah $+40 \%$ Konsentrat $+15 \%$ Indigofera zollingeriana $+0,3 \mathrm{mg} / \mathrm{Kg}$ BK Se $+40 \mathrm{mg} / \mathrm{Kg}$ BK Zn. Setiap perlakuan diulang sebanyak lima kali. Hasil penelitian menunjukan bahwa sapi perah bunting yang diberikan Indigofera zolingeriana pada masa transisi menghasilkan perbedaan yang tidak nyata $(\mathrm{P}>0,05)$ terhadap nilai total protein, albumin dan globulin plasma darah sapi perah. Dinamika plasma albumin $(-2,-1,0,1,2)$ menunjukkan pengaruh yang nyata $(\mathrm{P}<0,05)$ terhadap perlakuan pada berbagai minggu relatif beranak. Kesimpulan dari penelitian ini adalah Indigofera zollingeriana dan penambahan mineral dalam ransum tidak memberikan pengaruh yang nyata terhadap profil protein plasma darah (total protein, albumin, dan globulin) sapi perah pada masa transisi.
\end{abstract}

Kata kunci: Indigofera zollingeriana, Masa transisi, Mineral, Profil total protein, Sapi perah

\section{Proteins Profile in Dairy Cows during Transition Period with Indigofera zollingeriana as Concentrate Replacement and Mineral Addition in Feed}

\begin{abstract}
This study aim to determine the dynamics of protein profiles (total protein, albumin, and globulin) of dairy cow plasma in the transition period with Indigofera zollingeriana a substitute of the concentrate and the addition of minerals in feed. This study used experimental method with a Completely Randomized Design (CRD). Twenty Friesian Holstein dairy cows with 7-8 month gestation age were divided into four treatment, specifically IZO= 45\% Elephant Grass $+55 \%$ Concentrate, IZ15 $=45 \%$ Elephant Grass $+40 \%$ Concentrate $+15 \%$ Indigofera zollingeriana, IZOM=45\% Elephant Grass $+55 \%$ Concentrate $+0,3$

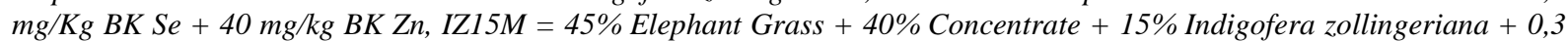
$m g / K g B K S e+40 \mathrm{mg} / \mathrm{Kg} B K \mathrm{Zn}$. Each treatment was repeated five times. The results showed that pregnant cows fed with Indigofera zolingeriana during the transition period produced similar plasma total protein, albumin and globulin of dairy cows $(P>0.05)$. The dynamics of plasma albumin $(-2,-1,0,1,2)$ showed a significant effect $(P<0.05)$ on the treatment at relative weeks of birth. This study concludes that Indigofera zollingeriana and the addition of minerals in the ration did not have a significant effect on the plasma protein profile (total protein, albumin, and globulin) of dairy cows during the transition period.
\end{abstract}

Keywords: Dairy cow, Indigofera zollingeriana, Minerals, Total protein profile, Transition period

\section{PENDAHULUAN}

Sapi perah merupakan komoditi ternak utama sebagai penghasil susu yang merupakan salah satu sumber protein hewani bagi manusia. Data menunjukkan bahwa konsumsi susu Indonesia pada tahun 2016 mencapai 11,8 liter/kapita/tahun (Pusat Data dan Sistem Informasi Pertanian, 2016). Salah satu faktor yang harus diperhatikan pada manajemen produksi sapi perah adalah masa transisi, dikarenakan banyaknya perubahan status fisiologis yang drastis terjadi lebih cepat dari mulai perubahan gizi pada sapi, persiapan fetus, laktogenesis, dan beranak (Johnson et

\footnotetext{
*Penulis Korespondensi: Iman Hernaman

Alamat: Jl. Raya Bandung-Sumedang KM. 21 Jatinangor, Sumedang 45363

E-mail: iman_hernaman
}

al., 2012). Masa transisi yakni 2 minggu sebelum beranak sampai 2 minggu setelah beranak (Drackley, 1999). Selama masa transisi, sapi perah mudah terkena gangguan metabolis dan infeksi penyakit (Grummer, 1995) yang diduga sebagai akibat dari penurunan daya tahan tubuh (Widhyari, 2005). Pada masa sebelum dan setelah beranak sering mengalami Negative Energy Balance (NEB), yakni kondisi tidak seimbangnya antara energi yang dikonsumsi melalui asupan pakan dengan energi yang digunakan oleh tubuh untuk produksi dan kebutuhan pokok (Baumgard et al., 2006). Salah satu solusi untuk meminimalisasi NEB adalah dengan pemberian pakan yang memiliki kandungan nutrisi yang tinggi serta penambahan mineral yang sangat dibutuhkan guna meningkatkan respon imunitas, memperbaiki status metabolik dan mengurangi penyakit. 
Pemberian pakan yang berkualitas dapat menunjang produktivitas sapi perah yang berasal dari hijauan dan konsentrat. Namun, harga konsentrat yang mahal mendorong peternak untuk menemukan bahan pakan sumber protein yang murah dengan cara mengoptimalkan lahan tidur yang belum termanfaatkan dengan baik, serta memiliki ketersediaan yang cukup sehingga bisa mengurangi jumlah pemakaian konsentrat. Salah satu hijauan alternatif tinggi protein yang potensial adalah Indigofera zollingeriana. Legum Indigofera zollingeriana diketahui memiliki kandungan nutrisi yang baik bagi ternak (Wilson dan Rowe, 2008). Indigofera zollingeriana merupakan leguminosa sumber protein (Herdiawan dan Krisnan, 2014). Penelitian mengenai pemberian Indigofera zollingeriana sebagai pengganti konsentrat terhadap dinamika total protein, albumin dan globulin darah sapi perah pada masa transisi belum pernah dilakukan. Penggunaan Indigofera zollingeriana sebagai pengganti konsentrat pada masa transisi diharapkan mampu memenuhi kebutuhan protein. Kebutuhan protein yang cukup merupakan faktor penting untuk meminimalisir kesetimbangan energi negatif dan turunnya fungsi imunitas selama masa transisi (Mallard et al., 1998). Perombakan protein plasma akan mempengaruhi nilai albumin dan globulin plasma darah sebagai bagian dari fungsi imunitas (Kaneko et al., 1997 dalam Irfan et al., 2011). Kandungan total protein plasma darah dan fraksinya dipengaruhi oleh kualitas pakan yang diberikan (Astuti et al., 2008 dalam Ardi, 2015).

Pakan hijauan di Indonesia seringkali kekurangan nutrisi salah satunya adalah kandungan mineral. Penambahan mineral pada pakan sapi perah masa transisi akan membantu mencukupi kebutuhan sapi perah yang tidak dapat dicapai hanya dari pakan rumput karena kualitas nutrisi hijauan khususnya di Indonesia masih rendah (Hutabarat, 2017). Penambahan mineral yakni Seng (Zn) dibutuhkan pada masa transisi untuk regenerasi luka pada saat involusi uterus, serta meningkatkan respon imunitas dengan membantu peran globulin pada sapi (Linder, 1992). Zn berperan dalam pertumbuhan dan aktivitas mikroba yang vital untuk proses fermentasi didalam rumen (Adawiah et al., 2007 dalam Widhyari, 2012). Keberadaan mikroba didalam rumen berpengaruh terhadap peningkatan nilai Volatile Fatty Acid (VFA) sebagai sumber energi sapi perah pada masa transisi (Sunaryati, 2013). Kebutuhan Zn untuk sapi perah bunting dan awal laktasi adalah 40mg/Kg BK (NRC, 1989). Selenium (Se) sangat bermanfaat bagi sapi perah pada masa transisi karena mineral ini meningkatkan daya tahan tubuh (Aviantri, 2012). Se membantu meningkatkan resistensi terhadap infeksi penyakit (Kurnia et al., 2012) seperti mencegah terjadinya mastitis (McDowell, 2003) dengan memediasi monosit untuk sampai ke sel-sel endotel. Monosit yang menempel pada sel endotel akan berdiferensiasi menjadi makrofag yang berfungsi memfagositosis partikel asing sehingga dapat meningkatkan efek imunitas (Cao et al., 2002).
Kebutuhan Se untuk induk yang sedang bunting atau sedang laktasi yakni sebanyak $0,3 \mathrm{mg} / \mathrm{Kg}$ BK (NRC, 1989).

Gambaran kesehatan pada sapi perah dapat dilihat dari profil metabolik darah karena dapat membantu mendiagnosa berbagai penyakit dan gangguan metabolisme (Ghahfarokhi, 2018; Oetzel, 2004). Salah satu parameter uji metabolik darah adalah total protein darah yang didalamnya terbagi 2 fraksi yakni albumin dan globulin (Walker et al., 1990; Payne et al., 1970). Kondisi tidak seimbangnya energi pada masa transisi mengakibatkan terjadinya perombakan cadangan energi dari protein dan lemak dalam tubuh, sehingga akan mempengaruhi kandungan total protein dan fraksinya yaitu albumin dan globulin dalam darah. Penurunan kandungan albumin dapat memperlambat laju perbaikan jaringan serta tanda bahwa terjadi inflamasi (Kristotomus, 2010; Lager dan Jordan, 2012) dan penurunan kandungan globulin dapat mengakibatkan immundefisiensi sehingga daya tahan tubuh melemah (Kaslow, 2010).

Hingga saat ini penelitian mengenai pengaruh pemberian Indigofera zollingeriana sebagai pengganti konsentrat disertai penambahan mineral $\mathrm{Zn}$ dan $\mathrm{Se}$ terhadap status metabolik sapi perah belum banyak dilaporkan. Sehingga penelitian ini diharapkan menjadi informasi dasar dalam memanfaatkan Indigofera zollingeriana sebagai pakan alternatif untuk menggantikan sebagian konsentrat dan penambahan mineral $\mathrm{Zn}$ dan Se dalam ransum guna melihat dinamika profil protein plasma darah untuk mengetahui status metabolik sehingga menunjang kesehatan sapi perah pada masa transisi. Kombinasi penggunaan Indigofera zollingeriana sebagai pengganti konsentrat dan penambahan mineral (Se dan $\mathrm{Zn}$ ) dalam pakan dapat mempertahankan kandungan total protein plasma, albumin dan globulin sapi perah pada masa transisi.

\section{MATERI DAN METODE}

Komisi Etik Universitas Padjadjaran Bandung telah menyetujui protokol penelitian ini dengan nomor registrasi: 0718070998. Desain penelitian termasuk perlakuan dan pakan telah dijelaskan pada Mayasari et al., 2019. Ternak penelitian yang digunakan adalah 20 ekor sapi perah Friesian Holstein (FH) betina bunting dengan bobot badan sekitar 450-500 kg, paritas 1 - 4 dan usia kebuntingan 7-8 bulan milik Balai Perbibitan dan Pengembangan Inseminasi Buatan Ternak Sapi Perah (BPPIB-TSP) Bunikasih, Dinas Ketahanan Pangan dan Peternakan. Ternak Bahan pakan penyusun ransum penelitian terdiri atas rumput gajah, konsentrat berbentuk mash dari CV. Cepogo Agro Lestari dan Indigofera zollingeriana dalam kondisi segar disediakan oleh pihak BPPIB TSP Bunikasih. Mineral $\mathrm{Zn}$ yang digunakan adalah zinc chlorid dengan dosis $40 \mathrm{mg} / \mathrm{kg} \mathrm{BK}$, hal ini didasarkan analisis yang telah dilakukan (Tabel 1) bahwa kandungan $\mathrm{Zn}$ yang ada pada Indigofera zollingeriana dan rumput gajah masih 
dibawah kebutuhan, ditambah persentase pemberian terbagi sesuai dengan perlakuan yang diberikan, dengan asumsi tersebut maka diberikan dosis tersebut agar tercukupi kebutuhannya (Tabel 2) namun masih baik secara klinis yakni dibawah $100 \mathrm{mg} / \mathrm{Kg}$ BK (Rahmat, 2004). Selenium yang digunakan adalah selenium reagent mixture Merck KGaA dengan dosis $0,3 \mathrm{mg} / \mathrm{kg} \mathrm{BK}$, menurut analisis yang dilakukan kandungan yang ada pada Indigofera zollingeriana dan rumput gajah sangat kecil yakni $<0,1 \mathrm{mg} / \mathrm{Kg}$ BK (Tabel 1), dengan penambahan $0,3 \mathrm{mg} / \mathrm{Kg}$ BK kebutuhan $\mathrm{Se}$ sapi perah dapat terpenuhi (Tabel 2). Ransum diberikan dua kali sehari untuk hijauan dan konsentrat, sedangkan untuk mineral diberikan satu kali sehari di pagi hari. Pemberian mineral dilakukan dengan cara mencampurkan mineral pada 500g konsentrat dan diberikan secara terpisah menggunakan baskom plastik.

Analisis proksimat kandungan nutrisi bahan pakan dilakukan di Laboratorium Nutrisi Ternak Ruminansia dan Kimia Makanan Ternak dan analisis mineral menggunakan metode Analisis Aktifasi Neutron (AAN) dilakukan di Badan Tenaga Nuklir Nasional (BATAN). Metode AAN merupakan salah satu teknik analisis nuklir yang memiliki limit deteksi rendah, spesifisitas tinggi, presisi, akurasi yang sangat baik untuk mayoritas unsur - unsur yang terdapat di alam, tidak merusak, multi elemen, dan dapat menganalisis sampel dengan ukuran kecil ( $<1 \mathrm{mg})$.

Pengumpulan data dilakukan 2 minggu sebelum beranak, saat beranak dan 2 minggu setelah beranak yaitu dengan mengambil sampel plasma darah dan susu yang dilakukan pada pagi hari. Masing-masing sapi

Tabel 1. Kandungan Nutrisi Bahan Pakan

\begin{tabular}{lccc}
\hline Kandungan Nutrisi & $\begin{array}{c}\text { Rumput } \\
\text { Gajah }\end{array}$ & Konsentrat & $\begin{array}{c}\text { Indigofera } \\
\text { zollingeriana }\end{array}$ \\
\hline Analisis Proximat $^{1}$ & 68,45 & 9,64 & 79,23 \\
Air (\%) & 15,10 & 11,30 & 11,46 \\
Abu (\%) & 10,99 & 18,50 & 28,15 \\
Protein Kasar (\%) & 1,62 & 10,22 & 2,22 \\
Lemak Kasar (\%) & 25,13 & 17,33 & 21,40 \\
Serat Kasar (\%) & 47,16 & 42,63 & 36,77 \\
BETN (\%) & 49,65 & 69,66 & 62,06 \\
TDN (\%) & 2916 & 3429 & 3022 \\
Energi bruto (Kkal/kg) & & & \\
Mineral & & & \\
Zn (mg/Kg BK) & 35,8 & 54,2 & 34,2 \\
Se (mg/Kg BK) & $\leq 0,11$ & 0,32 & $\leq 0,10$ \\
\hline${ }^{1}$ Laboratorium Nutrisi Ternak Ruminansia dan Kimia Makanan Ternak (2018) \\
${ }^{2}$ Analisis mineral menggunakan Metode AAN di Badan Tenaga Nuklir \\
Nasional (BATAN) (2018).
\end{tabular}

perah diambil darahnya sebanyak $5 \mathrm{ml}$ melalui vena coccygea. Darah dimasukkan ke dalam tabung EDTA. Sampel darah dibawa ke laboratorium untuk dilakukan sentrifuge dengan kecepatan 3000 rpm selama 10 menit untuk mendapatkan sampel plasma. Sampel plasma dimasukkan ke dalam tabung eppendorf kemudian disimpan dalam suhu $-20{ }^{\circ} \mathrm{C}$. Sampel plasma kemudian dilakukan thawing untuk dianalisis total protein dengan metode Biuret, albumin dengan metode Bromcresol Green (BCG) dan globulin dihitung secara manual (globulin $=$ jumlah nilai total protein - nilai albumin) (Kristotomus, 2010).

Penelitian ini dilakukan dengan metode eksperimental Rancangan Acak Lengkap (RAL), ternak dialokasikan pada 4 perlakuan berdasarkan bobot badan, produksi susu, paritas, BCS, dan estimasi beranak. Setiap perlakuan memiliki 5 kali ulangan. Perlakuan yang digunakan pada penelitian ini yaitu IZ0 $=45 \%$ Rumput Gajah $+55 \%$ Konsentrat, IZ15 $=45 \%$ Rumput Gajah $+40 \%$ Konsentrat $+15 \%$ Indigofera zollingeriana, IZOM $=45 \%$ Rumput Gajah $+55 \%$ Konsentrat $+0,3 \mathrm{mg} / \mathrm{Kg} \mathrm{BK} \mathrm{Se}+40 \mathrm{mg} / \mathrm{kg} \mathrm{BK} \mathrm{Zn}$, $\mathrm{IZ15M}=45 \%$ Rumput Gajah $+40 \%$ Konsentrat $+15 \%$ Indigofera zollingeriana $+0,3 \mathrm{mg} / \mathrm{Kg} \mathrm{BK} \mathrm{Se}+40$ $\mathrm{mg} / \mathrm{Kg}$ BK Zn. Analisis statistik yang digunakan untuk

Tabel 2. Kandungan Nutrisi Ransum Penelitian

\begin{tabular}{|c|c|c|c|c|}
\hline$\overline{\overline{\text { Bahan Pakan }}}$ & $\mathrm{IZ0}^{1}$ & IZ15 $^{1}$ & IZ0M $^{1}$ & IZ15M $^{1}$ \\
\hline R. Gajah (\%) & 45,00 & 45,00 & 45,00 & 45,00 \\
\hline Konsentrat (\%) & 55,00 & 40,00 & 55,00 & 40,00 \\
\hline I. zollingeriana $(\%)$ & 0,00 & 15,00 & 0,00 & 15,00 \\
\hline $\mathrm{Zn}(\mathrm{mg} / \mathrm{Kg} \mathrm{BK})$ & 0,00 & 0,00 & 40,00 & 40,00 \\
\hline $\mathrm{Se}(\mathrm{mg} / \mathrm{Kg} \mathrm{BK})$ & 0,00 & 0,00 & 0,30 & 0,30 \\
\hline \multicolumn{5}{|l|}{ Kandungan Nutrisi } \\
\hline$\overline{\mathrm{Abu}(\%)}$ & 13,01 & 13,03 & 13,01 & 13,03 \\
\hline Protein Kasar $(\%)$ & 15,12 & 16,57 & 15,12 & 16,57 \\
\hline Lemak Kasar (\%) & 6,35 & 5,15 & 6,35 & 5,15 \\
\hline Serat Kasar (\%) & 20,84 & 21,45 & 20,84 & 21,45 \\
\hline $\operatorname{BETN}^{2}(\%)$ & 44,66 & 43,79 & 44,66 & 43,79 \\
\hline $\mathrm{TDN}^{3}(\%)$ & 60,66 & 59,52 & 60,66 & 59,52 \\
\hline $\mathrm{Zn}(\mathrm{mg} / \mathrm{Kg} \mathrm{BK})$ & 45,92 & 42,92 & 85,92 & 82,92 \\
\hline $\mathrm{Se}(\mathrm{mg} / \mathrm{Kg} \mathrm{BK})$ & 0,18 & 0,13 & 0,48 & 0,43 \\
\hline \multicolumn{5}{|c|}{$\begin{array}{l}{ }^{1} \text { IZ01 = 45\% Rumput Gajah + 55\% Konsentrat; IZ15 = 45\% Rumput Gajah } \\
+40 \% \text { Konsentrat }+15 \% \text { Indigofera zollingeriana } ; \mathrm{IZ0M}=45 \% \text { Rumput } \\
\text { Gajah }+55 \% \text { Konsentrat }+0,3 \mathrm{mg} / \mathrm{Kg} \text { BK Se }+40 \mathrm{mg} / \mathrm{kg} \mathrm{BK} \mathrm{Zn} ; \mathrm{IZ} 15 \mathrm{M}= \\
45 \% \text { Rumput Gajah }+40 \% \text { Konsentrat }+15 \% \text { Indigofera zollingeriana }+0,3 \\
\mathrm{mg} / \mathrm{Kg} \text { BK Se }+40 \mathrm{mg} / \mathrm{Kg} \text { BK Zn } \\
{ }^{2} \mathrm{BETN}=\text { Bahan Ekstrak Tanpa Nitrogen } \\
{ }^{3} \mathrm{TDN}=\text { Total Digestable Nutrisi }\end{array}$} \\
\hline
\end{tabular}

Tabel 3. Profil Protein Plasma Darah (Total Protein, Albumin dan Globulin) Sapi Perah dalam Berbagai Kelompok Paritas3 (1, 2) pada Minggu Relatif Beranak (-2, -1, 0, 1, 2) (LSM5 \pm SEM5)

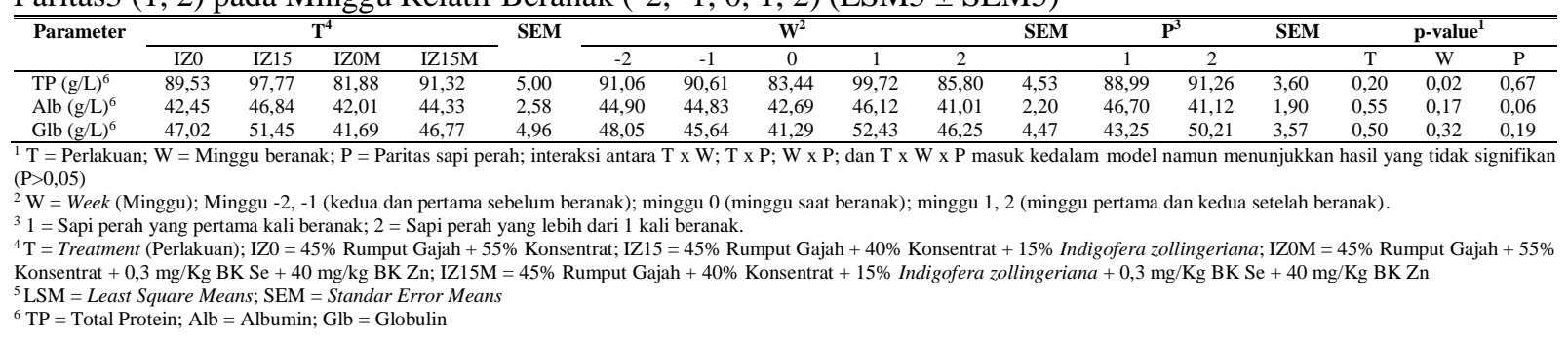


mengetahui pengaruh perlakuan terhadap peubah yang diamati adalah dengan menggunakan Statistical Analysis Software (SAS) University Edition, dengan Proc Mixed serta Autoregressive Covariance Structure. Fixed effect pada model ini adalah Treatment (IZ0, IZ15, IZ0M, dan IZ15M), Week yakni minggu ke -2, 1 (2 dan 1 minggu sebelum beranak), 0 (minggu saat beranak), 1, 2 (2 dan 1 minggu setelah beranak), Parity Grouping yakni 1 (belum pernah melahirkan), 2 (lebih dari sekali melahirkan) dan interaksi antar fixed effect (2-way interactions). Uji normalitas data dalam penelitian ini dengan melihat koefisien skewness dan kurtosis yang dihitung dengan Proc Univariate dalam program yang sama dengan batas nilai -2 sampai 2, sedangkan untuk mengetahui perbedaan antar perlakuan $(\mathrm{P}<0,05)$ dilakukan Uji Tukey. Dependent variable yang diuji adalah profil protein darah sapi perah yang terdiri dari total protein, albumin, dan globulin plasma darah.

\section{HASIL DAN PEMBAHASAN}

Hasil penelitian menunjukkan bahwa sapi perah bunting yang diberikan Indigofera zollingeriana untuk menggantikan sebagian konsentrat disertai dengan penambahan mineral dalam ransum pada masa transisi (dari 2 minggu sebelum sampai 2 minggu setelah beranak) menghasilkan perbedaan yang tidak nyata $(\mathrm{P}>0,05)$ terhadap nilai total protein plasma darah sapi perah (Tabel 3). Perbedaan yang tidak signifikan ini disebabkan asupan protein antar perlakuan tidak berbeda jauh yakni berkisar antara 15,12 - 16,57\% (Tabel 2). Nilai total protein pada penelitian diatas kisaran normal, seperti yang dijelaskan oleh Cozzi et al., (2011) bahwa nilai total protein pada sapi perah pada masa transisi berkisar $82 \mathrm{~g} / \mathrm{L}$.

Fungsi total protein darah membantu mengatur tekanan osmotik darah yang sangat esensial untuk menentukan permeabilitas membran sel (Adisuwirjo et al., 2001 dalam Utari et al., 2013). Penggunaan Indigofera zollingeriana sebagai pengganti konsentrat sebanyak $15 \%$ dalam ransum mampu mempertahankan nilai total protein dalam kisaran normal. Secara umum, penurunan nilai total protein terjadi pada minggu beranak sapi perah. Hal ini dapat disebabkan karena immunosupressan seperti stress saat beranak dan kebutuhan energi yang berlipat (Bell, 1995), sehingga asupan protein yang masuk diubah ke dalam bentuk energi untuk menyeimbangkannya. Secara umum, dapat dilihat (Gambar 1) bahwa terdapat kenaikan total protein pada minggu pertama setelah beranak, hal ini merupakan indikator meningkatnya homeostasis atau status kesehatan sapi pada kondisi normal. Berdasarkan hasil penelitian, sapi yang diberi Indigofera zollingeriana memiliki nilai konsumsi yang sama dengan sapi yang diberikan full konsentrat (49,50 vs 52, $72 \mathrm{Kg} /$ Ekor/Minggu) (Mayasari et al., 2019). Namun secara nilai rataan, sapi yang diberi Indigofera zollingeriana selama masa transisi memiliki nilai plasma protein yang lebih tinggi dibandingkan dengan full konsentrat walaupun tidak signifikan. Tingginya nilai protein diduga karena adanya zak atif dalam Indigofera zollingeriana yakni saponin sebesar 2,24\% (Abdullah et al., 2012) yang mampu melakukan defaunasi protozoa sehingga populasi bakteri rumen meningkat (Wina, 2012). Kandungan tanin yang terdapat pada Indigofera zollingeriana yakni 0,16 0,22\% (Herdiawan et al., 2014) atau masih dalam batas aman yakni $<4 \%$, berfungsi melindungi protein dari degradasi mikroba rumen secara berlebihan sehingga

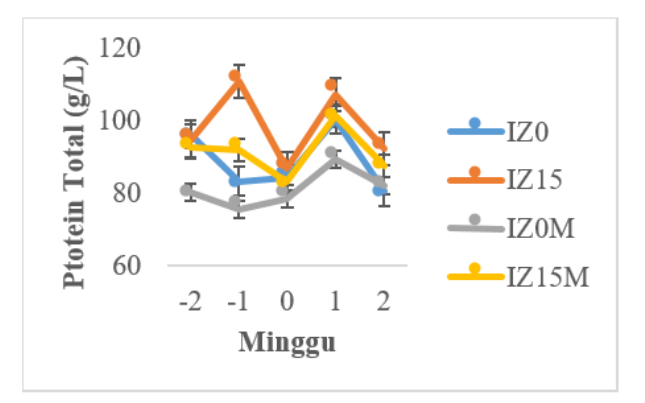

a
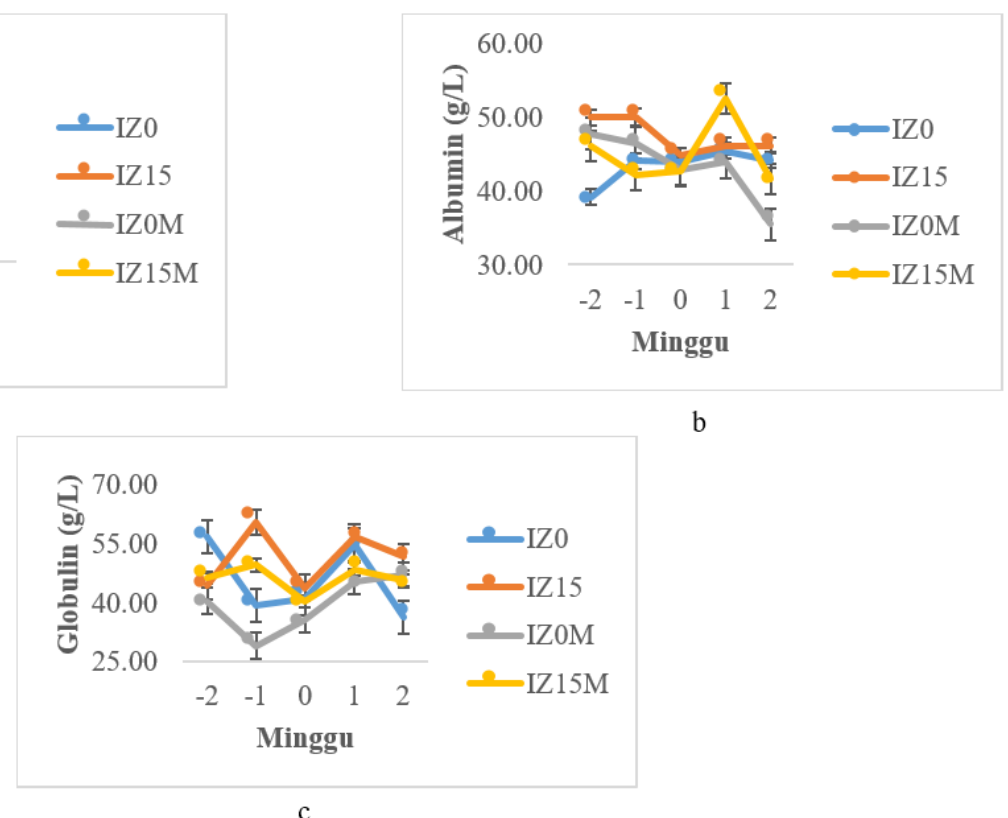

$\mathrm{b}$

Gambar 1. Pengaruh Perlakuan terhadap Nilai Total Protein ${ }^{\mathrm{a}}$, Albumin ${ }^{\mathrm{b}}$, Nilai Globulin ${ }^{\mathrm{c}}$ Plasma Darah Sapi Perah pada Berbagai Minggu Beranak 
menjadi protein by pass yang menguntungkan bagi ternak karena dapat diserap secara langsung oleh tubuh (Wina, 2012).

Sapi perah bunting yang diberikan perlakuan pada masa transisi menghasilkan perbedaan yang tidak nyata ( $>>0,05)$ terhadap albumin plasma darah sapi perah. Nilai albumin secara berurutan mulai dari yang tertinggi sampai yang terendah adalah sebagai berikut IZ15 46,84 g/L; IZ15M 44,33 g/L; IZ0 42,45 g/L; dan IZ0M 42,01 g/L. Nilai albumin pada penelitian ini masih dalam kisaran normal yakni berkisar 42,35 - 47 g/L (Gaona et al., 2012; Lager dan Jordan, 2012). Produksi albumin sejalan dengan asupan protein yang masuk ke dalam tubuh (Kurniawan, 2014) sehingga diperlukan perhitungan yang matang dalam pemberiannya (Tabel 2). Albumin merupakan fraksi protein yang sangat penting dalam penyembuhan luka (Suharjono et al., 2016). Secara umum, peningkatan nilai albumin (Tabel 3) menandakan proses penyembuhan luka pasca beranak semakin cepat, seperti yang dijelaskan Kristotomus (2010) bahwa albumin berperan dalam pembentukan jaringan baru, yang sangat bermanfaat pada saat involusi uterus.

Secara numerik, terdapat penurunan nilai albumin pada Parity grouping yang berbeda (Tabel 3), pada parity grouping 1 yakni sapi perah yang pertama kali bunting nilai albumin sebesar $46,70 \mathrm{~g} / \mathrm{L}$ sedangkan yang beranak lebih dari satu kali (parity group 2) nilai albumin hanya 41,12 g/L. Nilai albumin pada sapi perah yang beranak $>3$ kali lebih rendah dibandingkan sapi perah 2 kali beranak (Mayasari et al., 2017). Resiko terjadi inflamasi karena terinfeksi penyakit semakin besar pada sapi berumur tua, sehingga nilai albumin dapat turun pada saat inflamasi (Subronto, 2003; Friedman dan Fadem, 2010). Dinamika plasma albumin $(-2,-1,0,1,2)$ tidak memberikan pengaruh yang nyata $(\mathrm{P}>0,05)$ terhadap perlakuan pada berbagai minggu relatif beranak. Penyerapan dan transpor $\mathrm{Zn}$ dalam darah diatur oleh albumin yang kemudian diangkut ke berbagai jaringan didalam tubuh (Prasad et al., 1991) seperti ke hati, otak, dan sel eritrosit (Buckley, 2000 dalam Widhyari, 2012). Zn berperan dalam pertumbuhan dan aktivitas mikroba yang vital untuk proses fermentasi didalam rumen (Adawiah et al., 2007 dalam Widhyari, 2012). Keberadaan mikroba didalam rumen berpengaruh terhadap peningkatan kadar Volatile Fatty Acid (VFA) sebagai sumber energi sapi perah pada masa transisi (Sunaryati, 2013).

Sapi perah bunting yang diberikan perlakuan pada masa transisi menghasilkan perbedaan yang tidak nyata $(\mathrm{P}>0,05)$ terhadap globulin darah sapi perah. Nilai globulin darah secara berurutan mulai dari yang tertinggi sampai yang terendah adalah sebagai berikut IZ15 51,45 g/L; IZ0 47,02 g/L; IZ15M 46,77 g/L; dan IZ0M 41,69 g/L. Penggunaan Indigofera zollingeriana (IZ15) sebagai pengganti konsentrat sebagian dapat meningkatkan nilai globulin sebesar 9,42\% dari perlakuan kontrol (IZ0). Dinamika plasma globulin $(-2$, $-1,0,1,2)$ dan perbedaan paritas (kelompok paritas 1 dan 2) tidak memberikan pengaruh yang nyata $(\mathrm{P}>0,05)$ terhadap perlakuan pada berbagai minggu relatif beranak. Nilai globulin pada penelitian ini diatas kisaran normal seperti yang dijelaskan oleh Cozzi et al., (2011) bahwa nilai globulin darah pada sapi perah pada masa transisi berkisar $45 \mathrm{~g} / \mathrm{L}$. Dinamika yang terjadi sama seperti total protein dan albumin yakni terjadi peningkatan nilai pada minggu pertama setelah beranak. Globulin merupakan komponen immunoglobulin yang berfungsi menjaga imunitas tubuh (Hicks et al., 1998), penyakit metabolik sapi perah terjadi selama minggu pertama menyusui sehingga wajar bila produksi globulin meningkat di minggu pertama setelah beranak sebagai respon tubuh dalam menghadapi ancaman serangan penyakit (Goff dan Horst, 1997). Zn menunjang sistem imunitas sapi perah dengan membantu peran globulin (Linder, 1992) sebagai immunostimulator dalam proses peningkatan produksi sitokin oleh sel T hingga terjadi proliferasi dan diferensiasi sel. Sitokin bekerja untuk mengaktivasi sel T, sel B, monosit dan makrofag (Prasad et al., 2007 dalam Widhyari, 2012).

\section{KESIMPULAN}

Kesimpulan dari penelitian ini adalah pemberian Indigofera zollingeriana sebagai pengganti sebagian konsentrat dan penambahan mineral dalam ransum dapat mempertahankan dinamika total protein, albumin, dan globulin plasma darah sapi perah pada masa transisi. Berdasarkan hasil penelitian disarankan adanya penelitian lanjutan mengenai pemberian Indigofera zollingeriana dan suplementasi mineral tidak hanya untuk mempertahankan status kesehatan, lebih dari itu untuk meningkatkan status kesehatan sapi perah pada masa transisi.

\section{UCAPAN TERIMA KASIH}

Ucapan terima kasih penulis disampaikan Universitas Padjadjaran yang telah memberikan kesempatan dan kepercayaan kepada penulis untuk menjadi keluarga dari program Riset Kompetensi Dasar Universitas Padjadjaran (RKDU) dengan Ketua Peneliti Novi Mayasari, S.Pt., M.Sc., Ph.D. Ucapan terima kasih juga disampaikan pada Balai Perbibitan dan Pengembangan Inseminasi Buatan Ternak Sapi Perah (BPPIB-TSP) Bunikasih, Cianjur yang memberikan izin sebagai tempat pelaksanaan penelitian.

\section{DAFTAR PUSTAKA}

Abdullah, L.D. Apriastuti and T. Apdini. 2012. Use of Indigofera zollingeriana as forage protein source in dairy goat ration. Presented at The First Asia Dairy Goat Conference. Kuala Lumpur, Malaysia.

Ardi, J.P. 2015. Konsumsi Nutrisi Dan Gambaran Metabolit Darah Domba Pra Sapih yang Diberi 
Milk Replacer Mengandung Tepung Jangkrik atau Pupa Ulat Sutra. Karya Ilmiah. Departemen Ilmu Nutrisi dan Teknologi Pakan. Fakultas Peternakan Institut Pertanian Bogor. Bogor

Arora, S.P. 1989. Pencernaan Mikroba pada Ruminansia. Gadjah Mada University Press. Yogyakarta.

Aviantri, A. 2012. Manfaat Vitamin E dan Selenium Dalam Fermentasi In Vitro Ransum Yang Disuplementasi Asam Lemak Tidak Jenuh. Karya Ilmiah. Departemen Ilmu Nutrisi dan Teknologi Pakan. Fakultas Peternakan. Institut Pertanian Bogor, Bogor.

Baumgard, L.H., L.J. Odens, J.K. Kay, R.P. Rhoads, M.J. VanBaale and R.J. Collier. 2006. Does Negative Energy Balance (Nebal) Limit Milk Synthesis In Early Lactation. Department of Animal Sciences. The University of Arizona. Tucson.

Bell, A.W. 1995. Regulation of organic nutrient metabolism during transition from late pregnancy to early lactation. Journal of Animal Science 73(9): 2804-2819.

Cao, Y., J. Weaver, C. Reddy and L. Sordillo. 2002. Selenium deficiency alters the formation of eicosanoids and signal transduction in rat lymphocytes. Prostaglandins Other Lipid. Mediat 70: 131-143.

Cozzi, G., L. Ravarotto, F. Gottardo, A.L. Stefani, B. Contiero, L. Moro, M. Brscic and P. Dalvit. 2011. Short communication: Reference values for blood parameters in Holstein dairy cows: Effects of parity, stage of lactation, and season of production. Journal of Dairy Science 94: 38953901

Drackley, J.K. 1999. ADSA foundation scholar award. biology of dairy cows during the transition period: the final frontier. Journal of Dairy Science 82: 2259-2273.

Gaona, C.R., G.K. Alegria, A.E. Hernandez, and G.L. Patino. 2012. Protein and Mineral Metabolites for Dairy Cows During the Transition Period Under Tropical Conditions. Faculty of Agricultural Sciences. Universidad Nacional de Colombia. Sede Palmira. Valle del Cauca. Colombia.

Goff, J.P. and R.L. Horst. 1997. Physiological changes at parturition and their relationship to metabolic disorders. Journal of Dairy Science 80: 1260-1268

Grummer, R.R. 1995. Impact of changes in organic nutrient metabolism on feeding the transition dairy cow. Journal of Animal Science 73: 28202833.

Herdiawan, L. Abdullah dan D. Sopandi. 2014. Status Nutrisi Hijauan Indigofera zollingeriana pada Berbagai Taraf Perlakuan Stres Kekeringan dan Interval Pemangkasan. Indonesian Research Institue of Animal Production. Faculty of Animal Science. Bogor Agricultural University. Bogor

Hutabarat, J., Erwanto dan A.K. Wijaya. 2017.
Pengaruh umur pemotongan terhadap nilai protein kasar dan serat kasar Indigofera zollingeriana. Jurnal Riset dan Inovasi Peternakan 1(3): 21-24.

Kaslow, J.E. 2010. Analysis of serum protein. Santa Ana: 720 North Tustin Avenue Suite 104. CA

Krisostomus, C.Y.N. 2010. Kadar Total Protein, Albumin Dan Globulin Pada Darah Sapi Perah Betina Berumur Satu Sampai Dua Belas Bulan. Fakultas Kedokteran Hewan. Institut Pertanian Bogor.

Kurnia, F., M. Suhardiman, L. Stephani dan T. Purwadaria. 2012. Peranan nano-mineral sebagai bahan imbuhan pakan untuk meningkatkan produktivitas dan kualitas produk ternak. Prodi Master Bioteknologi. Fakultas Teknobiologi Unika Atma Jaya. Jakarta

Linder, M.C. 1992. Biokimia Nutrisi dan Metabolisme. A Parakkasi, Penerjemah. Penerbit Universitas Indonesia, Jakarta.

Mallard, B. A., J. C. Dekkers, M. J. Ireland, K. E. Leslie, S. Sharif, C. L. Vankampen, L. Wagter, and B. N. Wilkie. 1998. Alteration in immune responsiveness during the peripartum period and its ramification on dairy cow and calf health. Journal of Dairy Science 81: 585-595.

Mayasari, N., L.B. Salman., E.Y. Setyowati. 2019. Identifikasi biomarkers patofisiologi: penggunaan mineral anorganik dan Indigofera sp. untuk peningkatan produktivitas, reproduksi dan kekebalan alami sapi perah. Laporan Penelitian. Fakultas Peternakan. Universitas Padjadjaran. Bandung.

McDowell, L.R. 2003. Minerals in Animal and Human Nutrition. 2nd ed. Elsevier Science B.V., Netherlands.

National Research Council (NRC). 1989. Nutrient Requirement of Dairy Cattle. 6th Revised edit. National Academy Press. Washington, D.C.

National Research Council (NRC). 2001. Nutrisit Requirement of Dairy Cattle. 7th Revised edit. National Academy Press. Washington, D.C.

Rahmat, H. 2004. Peranan Mineral Seng (Zn) Dalam Tubuh Ternak. Makalah Pribadi Pengantar ke Falsafah Sains (PPS 702). Sekolah Pascasarjana. Institut Pertanian Bogor. Bogor.

Sirait, J., K. Simanihuruk dan R. Hutasoit. 2009. The potency Indigofera sp. as goat feed: production, nutritive value and palatability. In: Proceeding of International Seminar on Forage Based Feed Resources. Bandung, Indonesia. p. 4-7.

Suharlina. 2012. Manfaat Indigofera sp. dalam bidang pertanian dan industri. Jurnal Pastura 2(1): 30-33.

Sunaryati, A. Muktiani dan J. Achmadi. 2013. Suplementation of Curcuma xanthoriza and zinc proteinat to consumtion and milk energy production in dairy cows. Animal Agriculture Journal 2(1): 168-174.

Utari, B.W., H.E. Prasetiyono dan A. Muktiani. 2012. Milk quality of Ettawa Crossbreed goat fed on 
supplementation of protected protein in complete feed wafer based on agroindustrial by-product. Animal Agriculture Journal 1(1) : 427-441.

Widhyari, S.D. 2005. Patofisiologi Sekitar Partus Pada Kambing Peranakan Etawah: Kajian Peran Suplementasi Zincum Terhadap Respons
Imunitas Dan Produktivitas. Sekolah Pascasarjana Institut Pertanian Bogor. Bogor.

Wina, E. 2012. Senyawa sekunder dalam indigofera: Efek positif dan negatif serta teknologi mengurangi efek negatifnya. IAARD Press. Jakarta. 